\title{
Origin Recognition Complex Subunit 5
}

National Cancer Institute

\section{Source}

National Cancer Institute. Origin Recognition Complex Subunit 5. NCI Thesaurus. Code C34017.

Origin recognition complex subunit 5 ( $435 \mathrm{aa}, \sim 50 \mathrm{kDa}$ ) is encoded by the human ORC5 gene. This protein plays a role in the initiation of DNA replication. 